\title{
真空ギャップの絶縁破壊特性に及ぼす酸化の 影響と真空加熱処理による表面の清浄効果
}

\begin{tabular}{|c|c|c|c|c|c|c|}
\hline 正 & 員 & 塩 & 入 & & 哲 & （東 \\
\hline 正 & 員 & 1 & 瀬 & & 洋 & （東 \\
\hline 正 & 員 & 大 & 川 & 幹 & 夫 & （東 \\
\hline 正 & 員 & $t$ & 島 & & 啟 & （東 \\
\hline & 員 & 枸 & 父 & & 悟 & （東 \\
\hline
\end{tabular}

\section{Influence of Electrode Surface Oxidation on Breakdown Characteristics and Cleaning Effect by Heating Treatment in Vacuum}

Tetsu Shioiri, Member, Hiroshi Murase, Member, Mikio Okawa, Member, Iwao Oshima, Member, Satoru Yanabu, Member (Toshiba Corporation)

An experiment is carried out to investigate the influence of electrode surface oxidation on the vacuum breakdown characteristics, and the cleaning effect of heating treatments. An X-ray photoelectron spectroscopy is used to analyze the change of gas absorption on the electrode surface with the heating treatments. This analysis aims at identifying cleaning effect on a copper electrode surface.

With an increase adsorbed gas, the breakdown voltage decreases. With an increase on the temperature of heating treatments, the adsorbed gas is likely to be removed and the breakdown voltage increases. The oxidation degree of copper surface $\left(\mathrm{Cu}_{2} \mathrm{O}, \mathrm{CuO}\right)$ is strongly dependent on the exposure time to the air. With an increase in the temperature of the heating treatment, the copper becomes more deoxidized. This indicates that the heating treatment in vacuum provides substantial cleaning effects on the electrode surface.

キーワード：真空ギャップ, 絶緑破壊特性, 真空加熱処理, 酸化, XPS

\section{1. まえがき}

高真空を絶縁・消弧媒体とした真空遮断器用真空バ ルプの研究開発に扔いては, 電極材料およびその表面 状態がキーポイントとなる(1)(2)。これは，真空中の絶 緑破壊現象が電極表面の凸凹，付着物，酸化物などの 表面状態に著しく影響を受けるためである。これらの 要因による影響を特徵的に表している現象として, 破 壊を繰返すたびに破壊電圧が向上するという“コンデ イショニング効果”があげられる。これは，破壊を繰 返すことによって電極表面の付着物や酸化物が除去さ れ, 破壊電圧を安定化させ, 表面を清净化させる方法
として用いられる。しかし，コンディショニング時の 条件や電極材料によっては，逆に電極表面の荒れをま ねくという欠点もある(3)。このため，このようなコン ディショニングのほかに電極表面を清浄化させる方法 として, 真空中での加熱処理が従来加らよく用いられ ている。

例兊ば，杉野らは X 線光電子分光分析装置を用い て, 加熱処理後の電極表面を直接分析し，加熱処理の 最適条件を報告している(4)。しかしながら，加熱処理 による電極表面の吸着ガスの物理・化学状態の詳細な 変化についての報告は少ない。

また, Chattertonらは, 酸化した電極に高電圧を 
印加することにより吸着ガスの脱離とイオン化によっ て発生する Microdischargeについて理論的に検討し ている(5)。しかしながら，実用的に重要となる酸化の 程度と絶縁性能との関係についての報告は少なく，前 述した電極表面の清净化処理として知られる真空加熱 処理が，絶縁性能に与える効果についても明らかにさ れていないのが現状である。

そこで著者らは，電極表面の酸化の程度と破壊電圧 の関保, 真空加熱処理の温度と破壊電圧の関係につい て調查した。更に, $X$ 線光電子分光分析装置を用い て, 酸化の程度が異なる場合の真空加熱処理による酸 化物の物理・化学状態の変化を分析し, 真空加熱処理 による銅電極表面の清净効果について明らかにするこ とを試みた。

その結果, 吸着ガス量が大きい活ど破壊電圧は低下 し，また真空加熱処理の温度が高くなるほど，破壊電圧 も高くなることが明らかになった。これは，真空加熱 処理の温度が高いほど，電極表面の銅系酸化物 $\left(\mathrm{Cu}_{2} \mathrm{O}\right.$, CuO)が除去されるためであると考えられ，真空加熱 処理による銅電極表面の清净効果を明らかにした。

\section{2. 実験方法}

\section{$\langle 2 \cdot 1\rangle$ 破壊電王および前駆破壊電流の測定}

実験に用いた電極は高純度無酸素銅( $\mathrm{Cu}: 99.99 \%$ 以上 $\mathrm{O}_{2}: 10 \mathrm{ppm}$ 以下) 加らる直径 $80 \mathrm{~mm}$ の平行 平板電極である。電極間のギャップの長さは $2 \mathrm{~mm}$ ある。破壊電圧および前駆破壞電流の測定は, 図 I (a)に示す実験手順で行った。まず，電極を取付けた チャンバ内の圧力が $10^{-4} \mathrm{~Pa}$ になるまで真空引きを行 い, 次にチャンバを電気炉内に収納して，400ㄷ 20時間の加熱処理を行った。コンディショニングは,

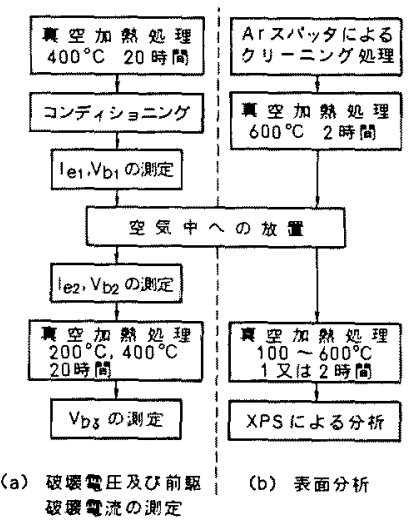

図 1 実験手順

Fig. 1. Experimental procedures.
交流電生で 5 分程度行い，十分に破壊電圧を高くして

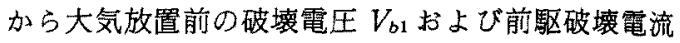
$I_{e_{1}}$ を測定した。破壊電圧と前駆破壊電流の測定注図

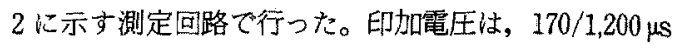
のインパルス波形を用いた。破壊電圧の測定は, 昇降 法により50\%破壊電圧を求めた。

次に，チャンバ内にりーク弁を通して空気を導入 し, 大気圧の状態で放置し，この放置時間を変えて害 験を行った。放置状態は, 温度が $20^{\circ} \mathrm{C}$ 前後で, 湿度 を変えて行った。その後, 更に $10^{-4} \mathrm{~Pa}$ 以下になるま で真空引きを行ってから, 破壤電圧 $V_{b 2}$ と前駆破壤

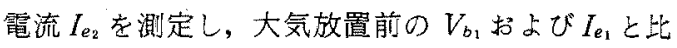
較した。その後, $200^{\circ} \mathrm{C}$ 放よび $400^{\circ} \mathrm{C} て ゙ 20$ 時間の真空 加熱処理を行い, 破壊電圧 $V_{b_{3}}$ 多测定し, 大気放置 前の $V_{b}$ と比較した。

$\langle 2 \cdot 2\rangle$ 分析方法 表面分析は, 数 $\AA$ 以下の表面 の状態の分析が可能な X 線光電子分光分析装置 (XPS と略記, KRATOS 社製 XSAM -800)を用い た。このXPS は, サンプルの加熱処理と表面分析を 同一容器内で行えるため, 加熱処理後のサンプルを大 気にさらすことなく表面分析を行うことができる。

表面分析の手順を図 1 (b)に示す。まず，清浄な 銅表面を得るためにサンプルを鏡面研磨（ダイヤモン ド $1 \mu \mathrm{m})$ し，真空中でサンプル表面をアルゴンスパ ッタによるクリーニング処理を行った。更に，600 $\mathrm{C}$ で2時間の加熱処理を行って，サンプル表面が十分に 清净化されたことをXPSにより確認した。その後サ ンプルを大気中に 2 時間放置し，表面分析を行った。

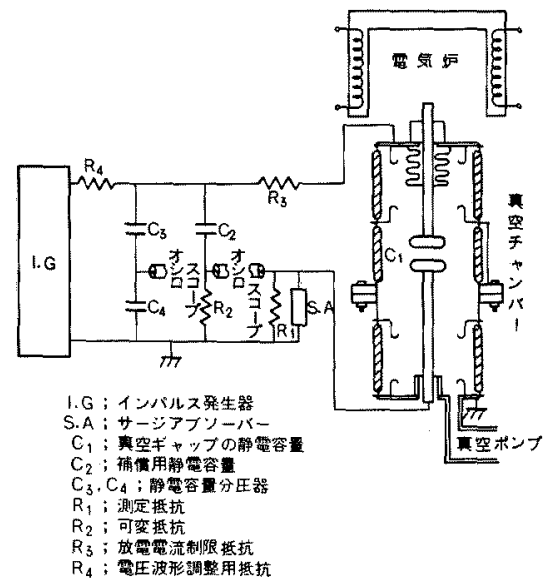

図 2 破壊電圧ちよび前駆破壊電流の 測定回路

Fig. 2. Circuit for measuring breakdown voltages and prebreakdown currents. 
表 1 測定したスペクトル

Table 1. Measurement spectrum.

\begin{tabular}{c|l|c}
\hline 測定元素 & \multicolumn{1}{|c|}{ 測定スペクトル } & 測定領域 $(\mathrm{eV})$ \\
\hline \multirow{2}{*}{$\mathrm{Cu}$} & $\mathrm{Cu} 2 p$ 光電子スペクトル & $925 \sim 975$ \\
\cline { 2 - 3 } & $\mathrm{Cu}$ LMMオージェ電子スペクトル & $906.5 \sim 926.5$ \\
\hline $\mathrm{C}$ & $\mathrm{C} 1 s$ 光電子スペクトル & $280 \sim 292$ \\
\hline $\mathrm{O}$ & $\mathrm{O} 1 s$ 光電子スペクトル & $526 \sim 538$ \\
\hline
\end{tabular}

また，放置時間が 20 日の場合についても表面分析を 行い，2 時間の場合と分析結果を比較した。ただし， 放置時の相対湿度を $100,200,300,400,600^{\circ} \mathrm{C}$ の 順に温度の低いほうから行った。各温度での加熱処理 時間は 2 時間であり, 一連の測定は同一サンプルで行 った。

XPS で測定したスペクトルは, 表 1 に示すように $\mathrm{Cu} 2 p, \mathrm{O} 1 s, \mathrm{C} 1 s$ 光電子スペクトルと $\mathrm{Cu} \mathrm{LMM}$ オ ージェスペクトルである。

\section{3. 絶縁破壊特性に及ぼす吸着ガスの影響と 真空加熱処理の効果}

〈3・1〉大気への放置による前駆破壊電流の変化

図 3 は大気への放置前後の印加電圧 $V$ と前駆破壊 電流 $I_{e}$ を比較したものである。大気中に 2 分間放置 しただけでも前駆破壊電流は, 大きく減少している。 これは, 大気へ放置したことによって電極表面へ大気 の気体分子が吸着し, 前駆破壊電流が变化したものと 考号れる。一般に真空ギャップの前駆破壊電流 $I_{e}$ は次式のような Fowler-Nordheimの式で表され $3^{(6)}$ 。

$$
\begin{aligned}
I_{e}= & \frac{1.54 \times 10^{-6}(\beta E)^{2} \times A}{\phi} \\
& \times \exp \left\{\frac{-6.83 \times 10^{7} \times \phi^{3 / 2}}{\beta E}\right\}
\end{aligned}
$$

ここに, $E$ : 印加電圧 $V$ をギャップdで割 つた平均電界, $\beta:$ 電界強化係数, $\phi:$ 電極

の仕事関数, $A$ : 電界放射面積

電極が大気への放置時間内に気体分子を吸着したこ とによって, (1)式の $\beta$ や $A$ は変化せず, 仕事関数 $\phi$ のみが変化したものと仮定して, 仕事関数 $\phi$ の変 化を算出する。放置前の銅電極の仕事関数を $4.5 \mathrm{eV}$ とし, 図 3 の放置前の $V-I_{e}$ 特性から求めた $\beta$ および $A$ は, 前述したように放置後も変化しないものと仮 定する。このようにして求めた放置後の銅電極の仕事 関数 $\phi$ は, $4.85 \mathrm{eV}$ となる (図 3 の破線)。従って大 気放置による気体分子の電極表面への吸着によって, 図. 3 に示した放置条件の場合, 仕事関数 $\phi$ は $0.35 \mathrm{eV}$

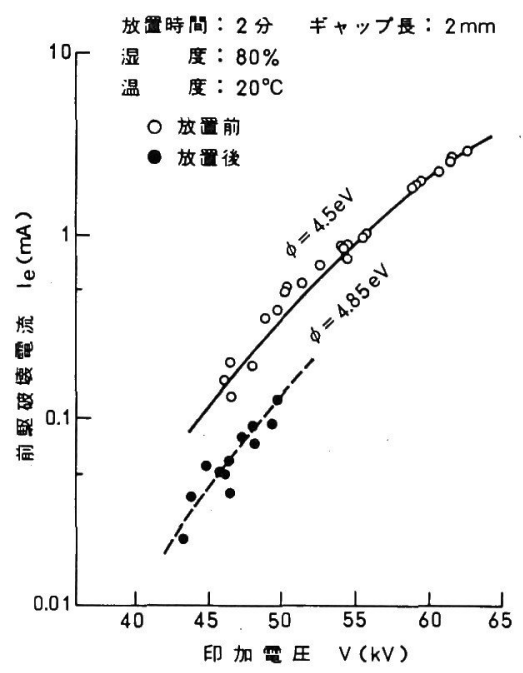

図 3 大気放置前後の印加電圧と前駆破壞 電流との関係

Fig. 3. Change of voltage-prebreakdown current characteristic with exposure to the air.

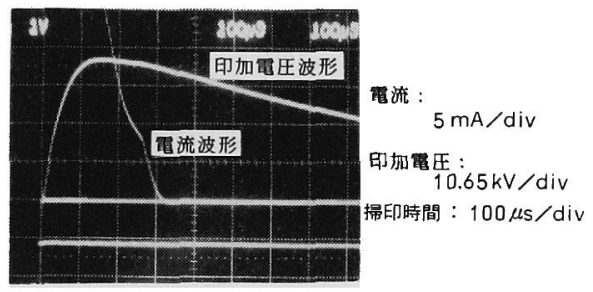

図 4 印加電圧と Microdischarge の 電流波形

Fig. 4. Waveform of applied voltage and "Microdischarge".

増加したことになる。 $\mathrm{CO}_{2}$ などのガスを導入して, 仕 事関数の変化量 $\Delta \phi$ を求めた鶴田らのデータ(7) と比較 して, $\Delta \phi$ がわずかに大きいのは, ガスの種類や圧力 の違いによるものと考えられる。

また，放置後の測定電流波形には，図 4 に示すよう に前駆破壊電流よりも数けた大きなパルス電流がたび たび観測された。放置前の電極においては，このよう なパルス電流は観測されず, Chatterton らの研究で 知られるMicrodischargeによるものと考えられる(5)。 大気放置で電極表面に形成された吸着がス層が，電圧 印加によって脱離し，パルス電流として表れているも のと考えられる。

〈3.2〉 大気への放置時間と破壊電圧の関係 図 5 は放置する前の破壊電圧 $V_{b_{1}}$ を基準にして, 放置後 
の破壊電圧 $V_{b 2}$ を $\mathrm{V}_{b 1}$ に対する割合とし，放置時間 との関係で表した。破壊電圧 $V_{b_{2}}$ は，いったん大気 に放置すると大きく低下し, 放置時間が長くなると共 に飽和する傾向にある。大気へ放置することによって 破壊電压が低下するのは，前駆破壇電流の測定からわ かったように，電界放射による電流が流れる前に，低 い電圧で吸着ガスの脱離による Microdischarge が発 生するためであると考えられる。

\section{〈3・3〉真空加熱処理が破壊電生に及ぼす効果}

前述したように，大気へ放置することによって破壊

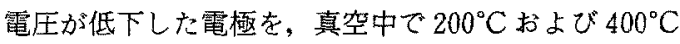
の加熱処理を行い, その後, 破壇電圧 $V_{b_{3}}$ を測定し

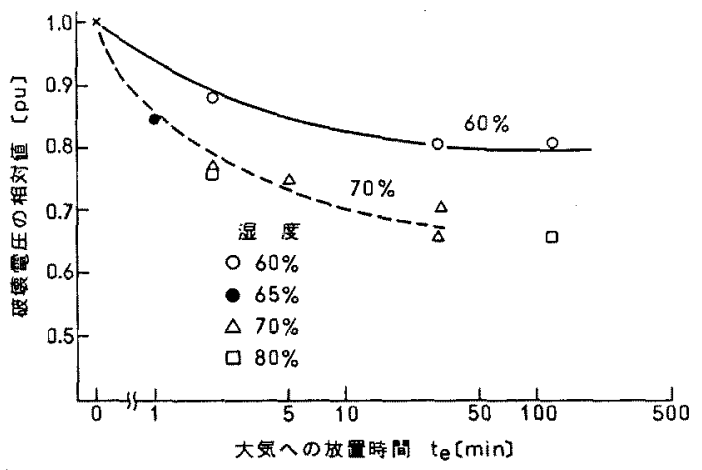

図 5 大気への放置時間と破壊電圧の 相対値の関係

Fig. 5. Relation between relative value of breakdown voltage and time of exposure to the air.

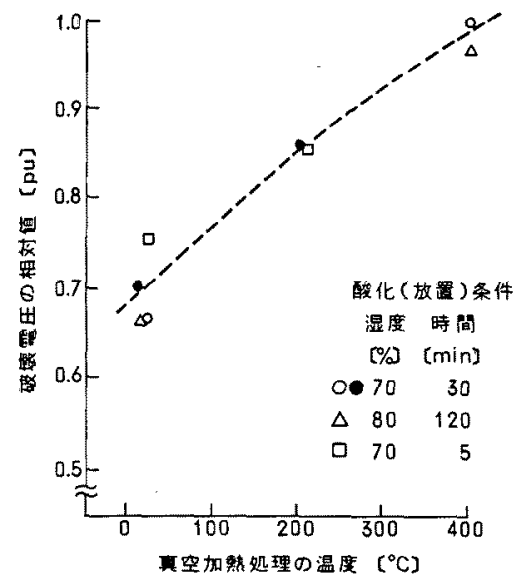

図 6 真空加熱処理の温度を変えた場合の 破壊電压の変化

Fig. 6. Relation between relative value of breakdown voltage and heating treatment temperature.
た。図 6 は，放置前の破壤電圧 $V_{b}$ を基準にして， 加熱処理後の破壊電压 $b_{b_{3}}$ を $V_{b_{1}}$ に対する割合で示 し，加熱処理温度との関係で示した。大気へ放置する ことによって破填電圧は低下しても, 真空加熱処理を 行うと，加熱処理の温度が高いほど，放置前の破壊電 压に近くなる。加熱処理温度が $400^{\circ} \mathrm{C}$ になると，ほ とんど放置前の破垍電圧に回復する。これは，電極表 面の吸着がスが真空加熱処理によって除去されたため と考えられるが，この点については，電極表面の分析 結果から次項で説明する。

\section{4. 真空加熱処理による電極表面の清浄効果}

〈4・1〉電極表面の元素の定量分析 銅 $\mathrm{Cu}$, 炭素 $\mathrm{C}$, 酸素 $\mathrm{O}$ の各元素の定量は, 各々の光電子スペクト ル強度のピーク面樍と, それに対する換算係数

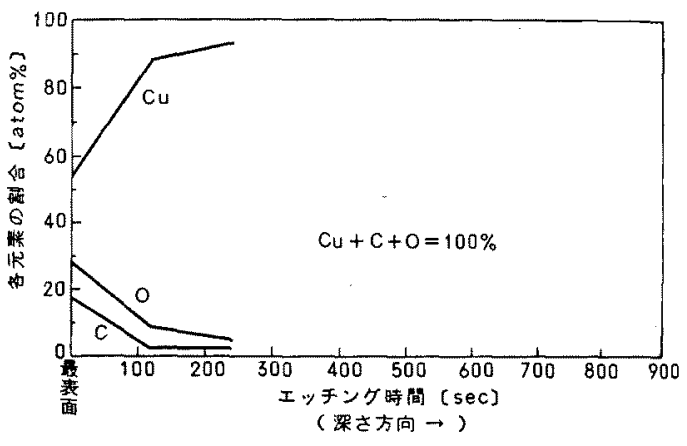

図 72 時間放置後の電極表面の媣さ方向の 元素分布

Fig. 7. Chemical element distribution of electrode at depths from the surface after $2 \mathrm{hrs}$ exposure to air.

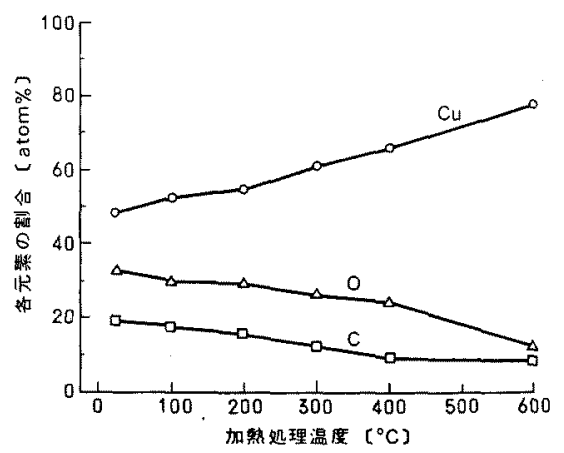

図 82 時間放置後の最表面における加熱 処理温度を変えた場合の各元素割合の変化

Fig. 8. Relation between chemical element ratio and heating temperature after $2 \mathrm{hrs}$ exposure to air. 
(KRATOS 社決定) を用いて求めた。図 7 は，2 時 間放置後の電極表面の深さ方向の元素分布である。た だし, 銅 $\mathrm{Cu}$, 炭素 C, 酸素 $\mathrm{O}$ の, 全量を $100 \%$ とし た。電極の最表面における銅元素以外の酸素や炭素の 量は，40〜50 atom\%もあることがわかる。しかし， 酸素や炭素の量は, 表面から深くなるほど隇少し, 電 極材料である銅元素の割合が增加している。このよう な吸着ガスでおおわれた銅電極に加熱処理を行って， 電極をXPS で分析した。図 8 は，2 時間放置後, 加 熱処理温度を変えた場合の最表面の分析結果である。 加熱処理温度が高いほど, 最表面における銅元素の露 出の割合が高くなっている。逆に, 酸素や炭素の割合 は, 加熱処理温度が高くなるほど減少しており, 真空 加熱処理による電極表面の清净効果を表している。

\section{〈4・2〉 電極表面の吸着ガスの物理・化学状態}

XPS は光電子スペクトルのピーク位置（各電子の 原子核に対する束縛エネルギー）やピーク形状から各 元素の化学状態に関する知見が得られる。図 9 は大気 に20日間放置後の電極の加熱処理温度を変えた場合 の, Cu 元素の光電子スペクトル波形の変化を示す。

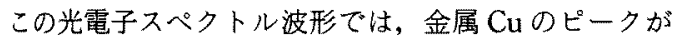
約 $932 \mathrm{eV}$ 付近に現れる。また, CuOのピークは約 $934 \mathrm{eV}$ 付近と, 更に約 $943 \mathrm{eV}$ 付近にシェイクアップ ピーク (光電子放出の際, 外核電子を同時に励起し, エネルギーロスした光電子ピータ）が現れる。しか

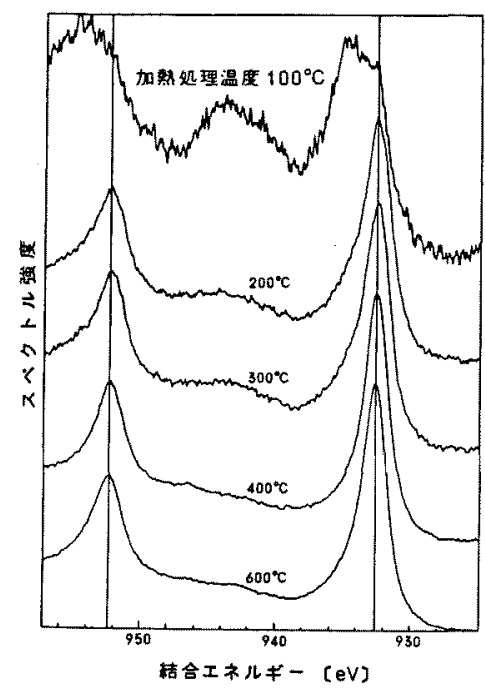

図 9 加熱処理温度を変えた場合の $\mathrm{Cu} 2 p$ 光電子スペクトル波形の変化

Fig. 9, $\mathrm{Cu} 2 p$ spectrum waveform variations with heating treatment temperature variations.

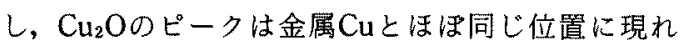
るので, 光電子スペクトル波形から金属 $\mathrm{Cu} と \mathrm{Cu}_{2} \mathrm{O}$ を区別することは困難である。図 9 に示した最表面 の光電子スペクトル波形の比較加ら, $100^{\circ} \mathrm{C}$ の加熱処 理では, $\mathrm{CuO}$ の存在を示方約 $934 \mathrm{eV}$ 付近と約 943 $\mathrm{eV}$ 付近のシェイクアップピークが現れている。加熱 処理温度が $200^{\circ} \mathrm{C}$ 以上になると $\mathrm{CuO}$ の存在を示すピ ークは小さくなっている。加熱処理温度が $200^{\circ} \mathrm{C}$ 以 上になると，逆に金属 $\mathrm{Cu}$ または $\mathrm{Cu}_{2} \mathrm{O}$ 状態の $\mathrm{Cu} の$ ピークは, 加熱処理温度が高くなるほど, 鋭く滑らか

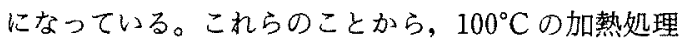
では $\mathrm{CuO}$ が多量に存在しているが, $200^{\circ} \mathrm{C}$ 以上にな ると, 金属 $\mathrm{Cu}$ または $\mathrm{Cu}_{2} \mathrm{O}$ 状態の $\mathrm{Cu}$ が加熱処理温 度と共に增加し, $\mathrm{CuO}$ は微量と考えられる。

これに対して大気への放置時間が短い2 時間の場合 の最表面の $\mathrm{Cu}$ の光電子スペクトル波形には, 図 9 で 説明したような $\mathrm{CuO} の$ 存在を示すピークは現れなか った。従って $\mathrm{Cu} の$ 化学状態として金属 $\mathrm{Cu}$ と $\mathrm{Cu}_{2} \mathrm{O}$ を区別するために，Cu LMMオージェ電子スペクト ルを測定した。図 10 は加熱処理温度を変えた場合の オージェ電子スペクトル波形の変化を示す。この $\mathrm{Cu} \mathrm{LMM}$ オージェ電子スペクトル波形に扔いて, 金 属 Cuのオージェピークは, 結合エネルギーが $918.6 \mathrm{eV}$ 付近, $\mathrm{Cu}_{2} \mathrm{O} て ゙ は 917 \mathrm{eV}$ 付近に現れる。従って, 図

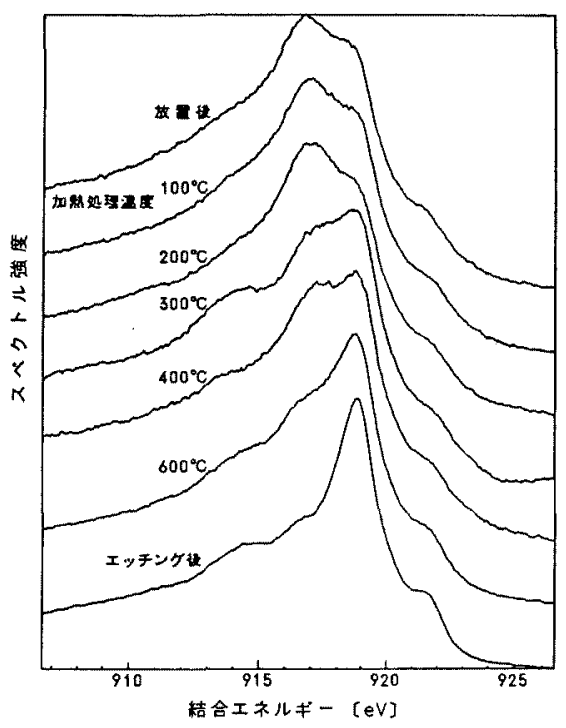

図 10 加熱処理温度を変えた場合の $\mathrm{Cu}$ LMM オージェスペクトルの変化

Fig. 10. $\mathrm{Cu}$ LMM auger spectrum waveform variations with heating treatment temperature, variations. 


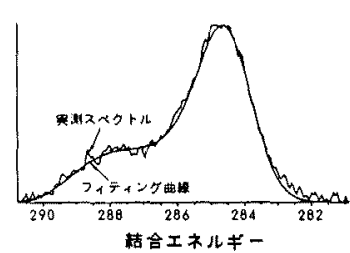

(a) 䒠测激形とフィティング曲線

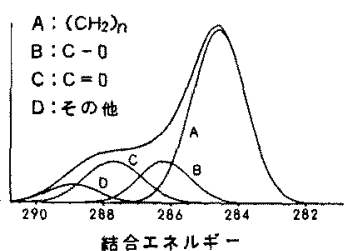

(b) スパトル波形解析

図 $11 C_{1 s}$ 光電子スペクトルによる炭素系 化合物の解析

Fig. 11. $\mathrm{C}_{1 s}$ photoelectron spectrum analy sis for carbon compounds.

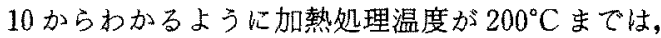

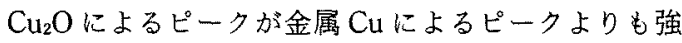

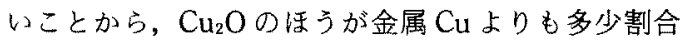
が高いものと考えられる。金属 $\mathrm{Cu}$ および $\mathrm{Cu}_{2} \mathrm{O} の$ 各 ピークの強度比は，加熱処理温度が高くなるほど，金 属 $\mathrm{Cu}$ の割含が高くなり, 逆に $\mathrm{Cu}_{2} \mathrm{O}$ の割合が減少し ていることを示している。これもまた，真空加熱処理 による電極表面の清浄効果を表している。

更に，炭素Cの化学状態を推定するために炭素の 光電子スペクトルの波形解析を試みた。炭素との結合 が考えられるのは，八イドロカーボン $\left(\mathrm{CH}_{2}\right)_{n}, \mathrm{C}-\mathrm{O}$, $\mathrm{C}=\mathrm{O}$ 結合であるので，実測で得られた炭素の光 電子スペクトルをこの3 種類について解析した。図11 (a)は，2 時間放置後(加熱好理なし)の最表面の実測 した㞸素の光電子スペクトル波形とそのフィティング 曲線である。図 11(b)は，そのフィティング曲線を 前述した 3 種類の光電子スペクトル波形に分けたもの である。図 11(b)の波形解析においてハイドロカー ボン $\left(\mathrm{CH}_{2}\right)_{n}$ の仮定波形を $A, \mathrm{C}-\mathrm{O}$ 結合を $\mathrm{B}, \mathrm{C}=\mathrm{O}$ 結合を $C$ に示す。解析結果は炭素系化合物として,

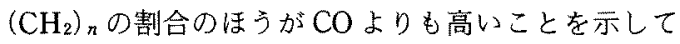
いる。図 12 は，各加熱処理温度でのC $\mathrm{Is}$ 光電子スぺ クトル波形を解析し， $\left(\mathrm{CH}_{2}\right)_{n}$ おょび $\mathrm{CO}$ の割合と加 熱処理温度との関倸で表した。加熱温度が高くなって も，炭素系化合物 $\left(\mathrm{CH}_{2}\right)_{n}, \mathrm{CO}$ ○全量が少なくなるだ けで, $\left(\mathrm{CH}_{2}\right)_{n}$ と $\mathrm{CO}$ との割合は, それ活ど変化して いないことがわかった。

以上のような分析結果から，2時間放置後（加熱処 理なし）の最表面の物理・化学状態は，量的に次の上 うな開係となる。

$$
\mathrm{Cu}_{2} \mathrm{O}>\text { 金属 } \mathrm{Cu}>\left(\mathrm{CH}_{2}\right)_{n}>\mathrm{CO}
$$

例えば，図 5 の湿度 $60 \%$ で放置時間 120 分の場合 の電極表面の吸着ガスは，（2）式のような化学状態と なっている。

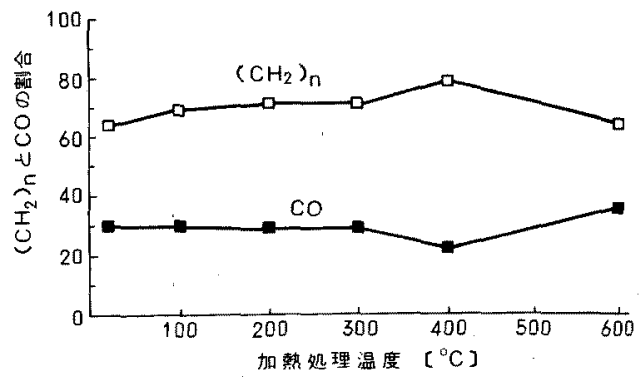

図 12 加熱処理温度を変えた場合の炭素系 化合物 $\left(\mathrm{CH}_{2}\right)_{n}, \mathrm{CO}$ の割合の変化

Fig. 12. Relation between ratio of $\left(\mathrm{CH}_{2}\right)_{n}$, $\mathrm{CO}$ and heating treatment temperature.

前述したように，大気放置によって破䫱電圧が低下 するのは（図 5)；電界放射による破垻が起こる前に， 電極表面の吸着ガスの脱離とイオン化によって Microdischarge が発生するためである。これに対して, 加熱処理温度が高くなるほど, 破㙲電生が高くなるの は(図6), 分析結果から明らかなように, Microdischargeに必要な電極表面の昅着ガスが加熱好理を行 うことによって除去されたためと考えられる。

\section{5.むすび}

真空中の銅電極の絶緣破坃特性に及ぼす電極酸化の 影響や，真空加熱処理による電極の清浄効果について 調查した結果を要約すると次のようである。

（1）清浄な電極を大気に放置すると破壊電圧は， 大きく低下するが，真空加熱処理を行うことにより， 放置する前の破壊電压に回復する。

（2）酸化の程度によって，銅系酸化物の化学状態 $\left(\mathrm{Cu}_{2} \mathrm{O}, \mathrm{CuO}\right)$ は異なるが，いずれの場合も加熱処理 の温度が高いほど銅系酸化物が除去されるので, 銅元 素の露出の割合が高くなり，真空加熱好理による電極 の清浄効果を明確に表している。

（3）XPSによる分析結果から，電極最表面の物 理・化学状態の量的関係を解析した結果, 例えば放置 時間 2 時間，相対湿度 60\%で加熱処理がない場合， 次のような関係となる。

$$
\mathrm{Cu}_{2} \mathrm{O}>\text { 金属 } \mathrm{Cu}>\left(\mathrm{CH}_{2}\right)_{n}>\mathrm{CO}
$$

最後に，本研究を進めるにあたり，有益な討論をい ただきました埼玉大学工学部電気工学科小林信一助 教授ならびに名古屋大学工学部電気工学科 大久保仁 助教授に深く感謝いたします。

(平成 3 年 1 月 7 日受付) 


\section{文献}

(1) T. Shioiri, I. Oshima, M. Honda, H. Okumura, H. Takaha. shi \& H. Yoshida : "Impulse Voltage Field Emission Characteristics and Breakdown Dependency upon Field Strength in Vacuum Gaps", IEEE Trans. Pow'er Apparatus Syst., PAS-101, 4178(1982)

(2) M. Okawa, T. Shioiri, H. Okubo \& S. Yanabu: "Area Effect on Dielectric Breakdown of Copper and Stainless Steel Electrode in Vacuum", IEEE Trans. Elect. Insulation, 23, 77(1988)

(3) 塩入: 「最近の真空遮断器用真空バルブの絶縁技術」, OHM, 74, No.8, 57 (昭 62)

（4）杉野・曾禍・鳥山・光井: 「真空加熱処理による銅電極表面の 清浄効果の検討」, 電学論 A, 102, 141 (昭 57)

(5) 例えば, J. M. Meek \& J. D. Craggs 編, ELECTRICAL BREAKDOWN OF GASES, p. 151(1978) Wiley \& Sons

(6) R. H. Fowler \& L. Nordheim: "Electron Emission in Intense Electric Field", Proc. Roy. Soc., 119, 173(1928)

(7) K. Tsuruta: "Change in Work Function of Vacuum-Gap Electrode by Residual Gas Adsorption", Japan J. Appl. Phys., 25, No. 4. 65(1986)

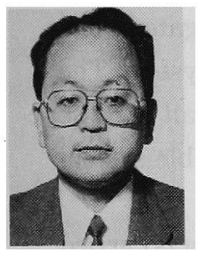

\section{塩入哲 (正員)}

昭和 30 年 5 月 7 日生。 49 年 3 月 長崎県立大村工業高校電気科卒業。 同年 4 月 (株) 東芝入社。重電技術研 究所にて, 主として真空遮断器の絶 縁技術の研究に従事。

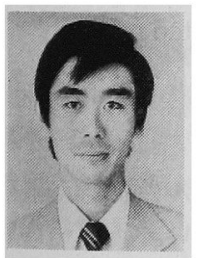

\section{村 瀬 洋 (正員)}

昭和 27 年 7 月 9 日生。 55 年東京 工業大学電気工学専攻博士課程修 了。55 年 4 月 (株) 東芝入社。59 年 より西ドイツ・ミュンヘン工科大学
に留学。工学博士。以後, 高電圧絶緑現象, GIS 中の 急しゅん波サージ現象の研究に従事。

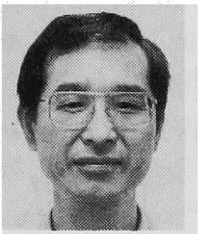

\section{大川 幹 夫（正員）}

昭和 10 年 9 月 8 日生。 33 年 3 月 名古屋大学工学部電気工学科卒業。 同年 4 月東芝に入社。主として, 真 空遮断器, 真空開閉器などの研究,

開発，設計に従事。IEEE 会員。

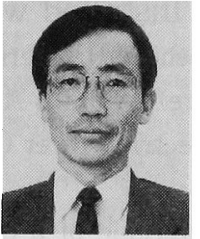

\section{大島䛓（正員）}

昭和 21 年 4 月 28 日生。 44 年 3 月九州工業大学卒業。工学博士。同 年 4 月 (株) 東芝入社。以来, 高電圧 開閉装置, 真空遮断器, 高電圧蔦1 リスタバルブおよびパルスパワー技術に関する研究に 従事。

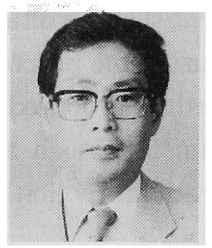

\section{柳 父悟（正員）}

昭和 16 年 7 月 15 日生。 39 年 3 月東京大学工学部電気工学科卒業。 47 年イギリス・リバプール大学 $\mathrm{Ph} . \mathrm{D}$ 。工学博士。39 年 4 月 (株) 東 芝入社。以来, 高電圧絶緑現象, 遮断現象, 高電圧大 電流試験法などの研究, 高電圧開閉保護装置の開発な どに従事。 57 年および 63 年電気学会進歩賞, 58 年同 論文賞。IEEE Fellow, Current Zero Club 会員。 